Bagus Endar B. Nurhandoko*, Rizal Kurniadi, Susilowati, Kaswandhi Triyoso, Sri Widowati, M. Rizka Asmara Hadi, M. Rizal Abda, Rio K. Martha, Elfa Fatiah, and Insan Rizal Komara

\title{
Integrated Subsurface Temperature Modeling beneath Mt. Lawu and Mt. Muriah in The Northeast Java Basin, Indonesia
}

https://doi.org/10.1515/geo-2019-0027

Received June 10, 2018; accepted March 19, 2019

\section{Introduction}

Knowledge of the subsurface temperature is an essential factor for petroleum exploration, geothermal energy prospection, and revealing some geological phenomena. This study was conducted to reveal the major features of the subsurface temperature distribution beneath a survey line from Mt. Lawu to Mt. Muriah in the Northeast Java Basin.

Previous authors initiated the research on subsurface temperature modeling. Some of them suggested methods for the estimation of subsurface temperature by combining numerical modeling with geostatistical interpolation up to a $500 \mathrm{~m}$ depth [1] or for a 3D estimation of subsurface temperature distribution by integrating well and groundlevel data in a case study in Germany [2]. Another paper also explained an investigation of subsurface temperature for the assessment of underground geothermal potential in France [3]. All of these references emphasize geostatistical data processing.

In this paper, we present the laboratory conductivity measurement of all possible lithology samples beneath the survey line. We use a method integrating both field and laboratory measurement data to achieve an accurate subsurface temperature profile. This paper presents subsurface temperature profiling beneath a measurement line from the south to the northern part of Java. The methods integrate various input data from field measurement, core laboratory measurement, and a modeling process. This method successfully produces a subsurface temperature profile that matches with geological phenomena.

\footnotetext{
^Corresponding Author: Bagus Endar B. Nurhandoko: Physics Department, Institut Teknologi Bandung, Indonesia Rock Fluid Imaging Lab, Indonesia, E-mail: bagusnur@bdg.centrin.net.id , Tel.: +62-22-426-90019 Rizal Kurniadi: Physics Department, Institut Teknologi Bandung, Indonesia
}

Susilowati, Kaswandhi Triyoso, M. Rizka Asmara Hadi, M. Rizal Abda, Rio K. Martha, Elfa Fatiah, Insan Rizal Komara: Rock Fluid Imaging Lab, Indonesia Sri Widowati: Telkom University, Indonesia 


\subsection{Study Area}

The survey line overlaid on a geographical map is shown in Figure 1. The survey line is also overlaid on a geological map [16-19, 26], as shown in Figure 2. The survey line is through the active volcano Mt. Lawu (Point A), the active thrust faults in the Kendeng zone (Points B and C), and the strike-slip fault of the RMKS (Rembang-MaduraKangean-Sakala) fault zone (Points D, E, and F). The survey line passes the extinct volcano of Mt. Muriah (Point G) in the northern part of the measurement line, and it also passes through thousands of years of hot mud eruption called Bledug Kuwu (Point D).

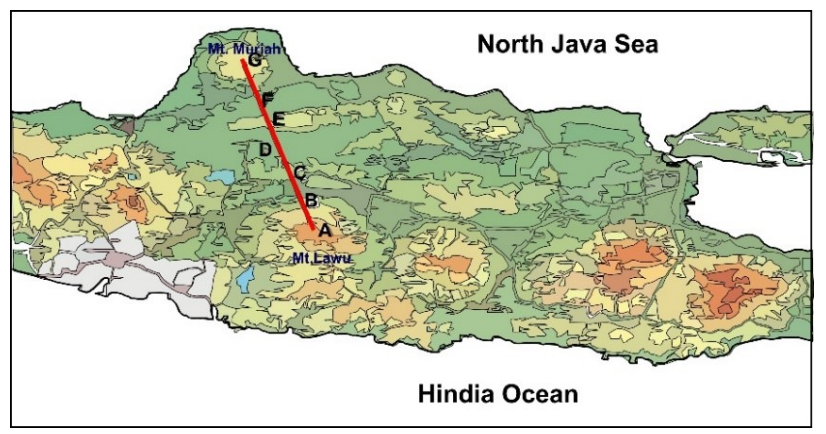

Figure 1: The measurement line is in the western part of East Java Basin. The red-yellowish color indicates mountains. On the measurement line, points $A-G$ indicate the positions of various phenomena.

Figure 3 shows the regional stratigraphy of East Java Basin. Tmpk, Tml, Tmt, Tmw, Tmn, Qvlm, and Qvtm represent the names of the formations. Tmpk indicates Kalibeng Formation, which contains marl, intercalated sandstone, and tuffaceous-calcareous rock. Tml denotes the Ledok Formation. This formation consists of gray claystone, marl, and bedded calcarenite, occasionally containing glauconitic sandstone interbeds. Tmw indicates the Wonocolo Formation, which contains claystone with interbeds of limestone and with glauconitic sandstone in the lower part. The unit contains Foraminifera and is overlaid by the nonconformity of the Ngrayong Formation. Tmn represents the Ngrayong Formation, which contains layer of claystone, calcareous sandstone, and limestone in the lower region and sandy claystone in the upper region. Tmt denotes the Tawun Formation, which consists of claystone and limestone with sandstone, siltstone, and calcarenite interbeds. Tmt and Tmn are members of the Tuban Formation. Qvlm and Qvtm indicate the products of volcanic activity, such as lava, tuff, and lahar rock.

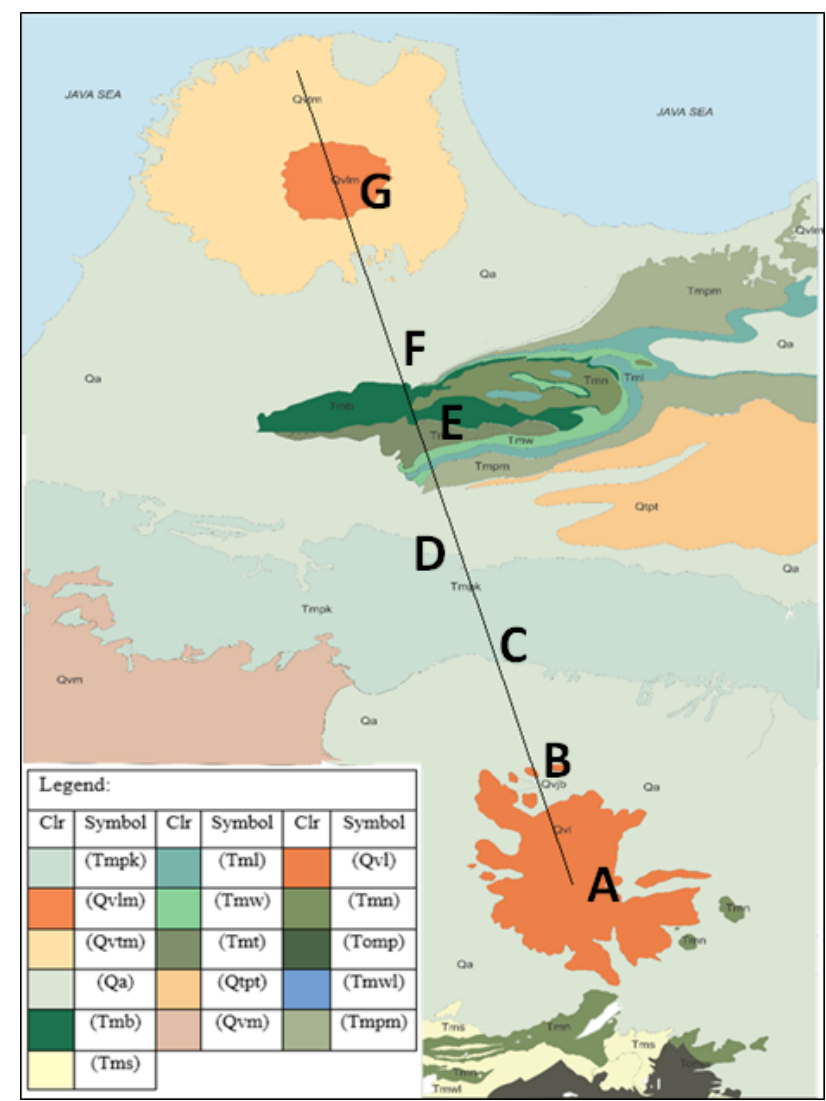

Figure 2: Geological map showing the surroundings of the measurement line. Colors indicate the names of Formations. Tmpk denotes Kalibeng Formation, Tml indicates Ledok Formation, Tmw indicates Wonocolo Formation, Tmn denotes Ngrayong Formation, Tmt denotes Tawun Formation, and Qvlm is the product of volcanic activity, such as lava, tuff, and lahar rock of Mt. Lawu. Qvtm indicates volcanic rock of Mt. Muriah. The map was compiled from the works of various authors [16-19, 26].

\section{Methods and results}

In this study, subsurface temperature modeling required measurement data from both in the field and in the laboratory. Measurements in the field to obtain the gradient temperature were carried out from wells along the survey line using a Pt100 thermometer. Along with measurements, we also collected rock samples that represented each lithology in the stratigraphic column. These rock samples were then measured in the laboratory to obtain rock conductivity values. In addition to field and laboratory measurements, Bouguer anomaly data were used in this study to create a subsurface geological model which was then transformed into a model of subsurface thermal conductivity based on the relation derived from laboratory measurements between the density and thermal conductivity of each rock sample. 


\begin{tabular}{|c|c|c|c|c|}
\hline \multicolumn{2}{|l|}{ AGE } & \multicolumn{2}{|r|}{ FORMATION } & $\begin{array}{l}\text { TECTONIC } \\
\text { EVENT }\end{array}$ \\
\hline \multirow{2}{*}{\multicolumn{2}{|c|}{ Holocene }} & Qvi & Lawu Yolcanic (OY) & \multirow{6}{*}{ 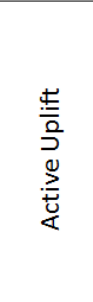 } \\
\hline & & Qvm & Merbabu Volcanic Breccia (Qvm) & \\
\hline \multirow{3}{*}{ PLEISTOCENE } & \multirow{2}{*}{ Late } & Qvim & Muria Lava (Qvim) & \\
\hline & & Qvtm & Muria Tuff (Qvtm) & \\
\hline & Early & Qtpt & Tambakromo Formation (Qtpt) & \\
\hline \multirow{2}{*}{$\begin{array}{l}\text { 岂 } \\
\text { U⿺ } \\
\underline{\underline{D}} \\
\underline{\alpha}\end{array}$} & Late & Tmpk & Kalibeng Formation (Tmpk) & \\
\hline & Early & Tmpm & Mundu Formation (Tmpm) & \multirow{5}{*}{ 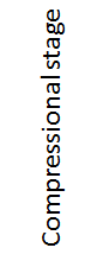 } \\
\hline \multirow{7}{*}{ 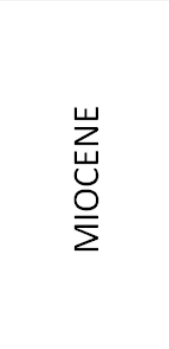 } & \multirow{2}{*}{ Late } & Tml & \multirow{2}{*}{$\begin{array}{l}\text { Ledok Formation (Tml) } \\
\text { Wonosari Formation (Tmwl) }\end{array}$} & \\
\hline & & Tmwl & & \\
\hline & \multirow{3}{*}{ Middle } & $T m w$ & Wonocolo Formation (Tmw) & \\
\hline & & Tmb & Bulu Formation (Tmb) & \\
\hline & & Tmn & Nrayong Formation (Tmn) & Sagging \\
\hline & \multirow{2}{*}{ Early } & Tmt & \multirow{2}{*}{$\begin{array}{l}\text { Tawun Formation (Tmt) } \\
\text { Semilir Formation (Tms) }\end{array}$} & \multirow{2}{*}{$\begin{array}{l}\text { Extensional } \\
\text { stage }\end{array}$} \\
\hline & & Tms & & \\
\hline OLIGOCENE & Late & Tomp & Panggang Formation(Tomp) & $\begin{array}{l}\text { Extensional } \\
\text { stage }\end{array}$ \\
\hline
\end{tabular}

Figure 3: Regional stratigraphy of East Java Basin (after [18]).

The basic theory of subsurface temperature estimation is Fourier's law (Eq. 1). This equation shows the relation between heat flow $(\mathrm{Q})$, thermal conductivity $(\mathrm{k})$, and the temperature gradient $(\mathrm{dT} / \mathrm{dz})$.

$$
Q=k d T / d z
$$

The subsurface temperature can be estimated by forward

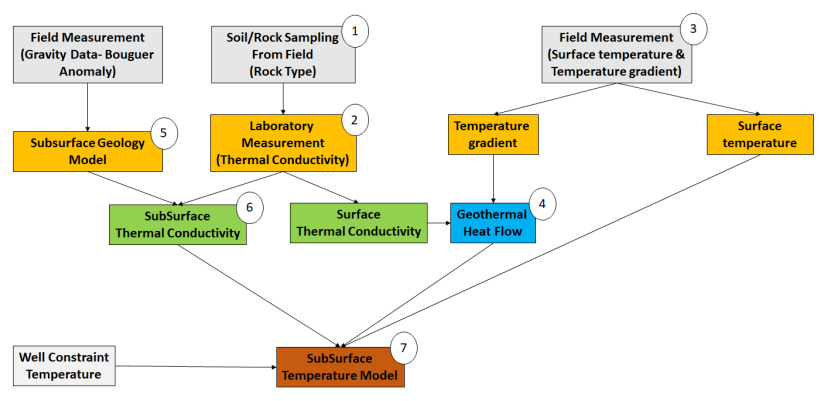

Figure 4: Workflow of integrated subsurface temperature modeling.

modeling of the temperature from the surface to the deeper zone using various input data, as shown by the workflow in Figure 4. The modelling requires both field and laboratory work.

The field work consisted of collecting rock samples that represent each lithology in the stratigraphic column and temperature measurements of wells found along the survey path. The samples of rock that were collected were then measured in the laboratory to obtain the values of thermal conductivity and density. The measured density values are used as a basis when creating a geological model based on Bouguer anomaly data, while the thermal conductivity values are used to transform the density values in the geological model to subsurface thermal conductivity profiles. Furthermore, this thermal conductivity profile is combined with the temperature gradient measurement results to produce a subsurface temperature model.

\subsection{Rock Sample Collection}

The rock samples were collected in various lithologies, i.e., carbonate (limestone), volcanic andesite rock, shale, clay, and sandstone. The rock samples should represent each lithology in the stratigraphic column as summarized in the regional stratigraphy of East Java Basin, shown in Figure 3.

Figure 5 shows photographs of several samples in different lithologies that were collected along the survey line. The density of the rock was the input data for modeling the geological subsurface using density modelling of the Bouguer gravity anomaly. The modeling of the subsurface temperature also requires information on the thermal conductivity of rocks. The modeling of thermal conductivity should be aligned with the subsurface geological model. Therefore, rock sample collection is essential for conducting density and thermal conductivity measurement.

\subsection{Laboratory Measurement of Thermal Conductivity}

The thermal conductivity measurement of each lithology unit used at least two samples. The samples of rock were cored and appropriately smoothed to a specific size of 3$4 \mathrm{~cm}$ in length and $3 \mathrm{~cm}$ in diameter. One measurement used two similar rock samples. The equipment shown in Figure 5 shows the measurement scheme of thermal conductivity. There are many temperature sensors in the equipment, and at least five temperature sensors should be attached to a sample of rocks to measure heat flow accurately. The equipment also has hot and cold reservoirs. The temperature of the water in the hot reservoir was kept constant or at a steady-state temperature by using a digital controller.

The data, such as time of measurement and temperature of the sensor, were collected simultaneously using a temperature-logging data system in real-time conditions. 


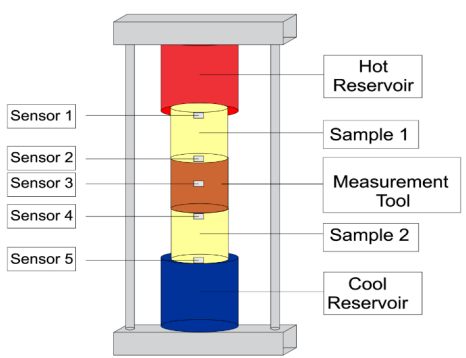

(a)

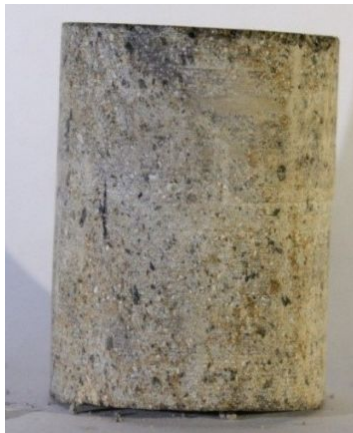

(b)

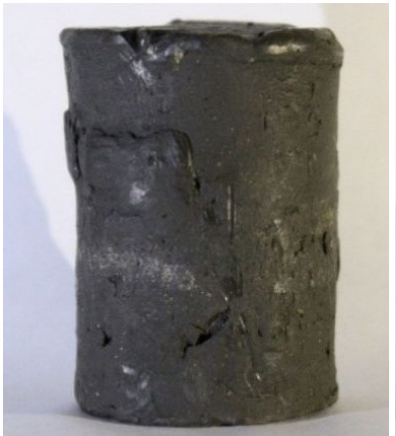

(c)

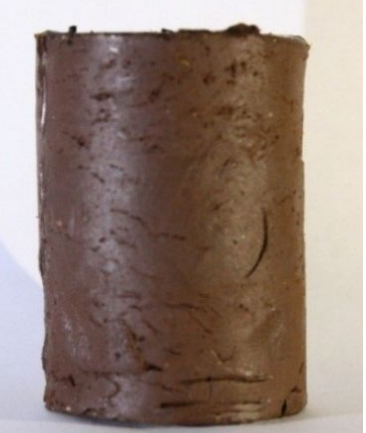

(d)

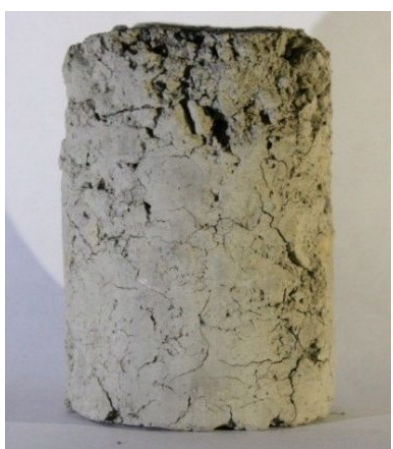

(e)

Figure 5: Thermal conductivity measurement. (a) Measurement equipment; (b) carbonate rock from Tegalrejo equal to Mio-Pliosen Kalibeng; (c) clay sample from Bledug Kuwu equal to Kalibeng; (d) tuff sample from Muktiharjo Mt. Muriah; (e) clay sample from Bago equal to Kalibeng.

The direct outputs of the measurements were the heat flow and the temperature gradient of the rock. Therefore, once we provided the heat flow and temperature gradient, the thermal conductivity of the rock sample was estimated by Equation (1):

$$
k=Q /((d T / d z))
$$

where $\mathrm{Q}$ indicates the thermal heat flow, $\mathrm{k}$ denotes the thermal conductivity of the rock, and $\mathrm{dT} / \mathrm{dz}$ represents the temperature gradient.

The thermal conductivity value is an average of those data collected over the whole measurement period (Table 2). Figure 6 shows the respective thermal conductivities of carbonate, shale, volcanic tuff, alluvial sample, and clay from mud eruption (Bledug Kuwu mud eruption).

\subsection{Field measurement of surface and gradient temperature}

To produce an accurate thermal gradient, we used a calibrated array RTD sensor (Pt100) thermometer. Temperature and temperature gradient measurements were taken. Table 3 shows details of the location measurement results
Table 1: Density of rock samples along the measurement line.

\begin{tabular}{|cc|}
\hline Sample & Density (g/cc) \\
\hline Cherts & 2.69 \\
Tegalrejo Carbonate (equal to Miocene-Pliocen Kalibeng) & 2.19 \\
South Java Metamorf equivalent Sampung Formation (Middle & 2.89 \\
Miocene) & \\
Lahar Rock & 2.47 \\
Sambungmacan Carbonate of Klitik Member, Kalibeng & 2.37 \\
Formation (Early Miocene to Pliocene) & \\
Bago Shale of Kalibeng Formation & 1.69 \\
BledugKuwu Clay equivalent Kalibeng Formation & 1.87 \\
Central Java Alluvial & 1.69 \\
Muktiharjo Tuff of Mt. Muria & 1.81 \\
Lawu Andesite & 2.7 \\
\hline
\end{tabular}

for every chosen point from Mt. Muriah to Mt. Lawu along the $130 \mathrm{~km}$ survey line. The measurements were collected from 35 wells. The wells were mainly shallow wells, but there were some deep wells from geothermal wells.

Figure 7 and Figure 8 represent, respectively, the distribution of the temperature of the water table and the temperature gradient from the southern part to the northern part of the line through Mt. Lawu, Sragen, Kendeng, Kuwu, Pati, and Mt. Muriah in the northern part of the survey line. There is strong variation in the values along the survey 


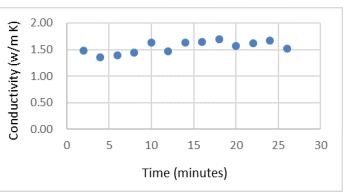

(a)

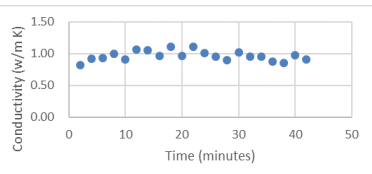

(c)

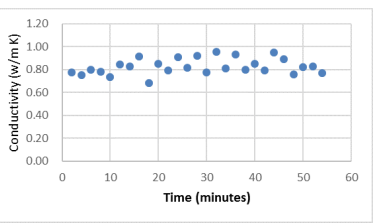

(e)

Figure 6: Thermal conductivity values of (a) Tegalrejo carbonate; (b) Bago shale; (c) Muktiharjo tuff; (d) alluvial; and (e) Bledug Kuwu clay.

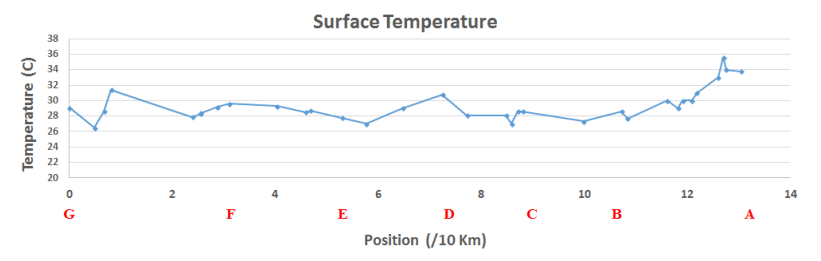

Figure 7: Temperature profile along the measurement line.

line which is caused by different geological phenomena. The Kendeng zone, shown by points D-E in Figure 1, has higher geothermal heat flow compared to the surrounding area.

\subsection{Geothermal heat flow calculation}

Geothermal heat flow is essential in the estimation of the subsurface temperature profile. The input data include the temperature gradient and the thermal conductivity [20] of samples obtained along the measurement line. Figure 9 shows the calculation result of the geothermal heat flow profile based on input data that was measured as described in Sections 2.2 and 2.3 along the survey line.
Table 2: Thermal conductivity of the rock samples.

\begin{tabular}{|cc|}
\hline Sample & Density (g/cc) \\
\hline Cherts & 2.69 \\
Tegalrejo Carbonate (equal to Miocene-Pliocen Kalibeng) & 2.19 \\
South Java Metamorf equivalent Sampung Formation (Middle & 2.89 \\
Miocene) & \\
Lahar Rock & 2.47 \\
Sambungmacan Carbonate of Klitik Member, Kalibeng & 2.37 \\
Formation (Early Miocene to Pliocene) & \\
Bago Shale of Kalibeng Formation & 1.69 \\
BledugKuwu Clay equivalent Kalibeng Formation & 1.87 \\
Central Java Alluvial & 1.69 \\
Muktiharjo Tuff of Mt. Muria & 1.81 \\
Lawu Andesite & 2.7 \\
\hline
\end{tabular}

\subsection{Subsurface Geology Modeling}

The subsurface geology model is the primary reference for obtaining a thermal conductivity model. In this paper, the subsurface geological model used Bouguer anomaly modeling that needs some constraints to reduce the ambiguity. The constraints of Bouguer anomaly modeling comprise lithologies of the surface, density of rocks, wells, and the geological model proposed by previous authors [5, 10, 21].

Figure 12 shows the subsurface geology model, which was redrawn based on references [10, 14] and [21, 22]. The Bouguer anomaly data refer to the gravity map by the Geology Agency of Indonesia in reference [23]. The Bouguer anomaly data along the survey line, as shown in Figure 13, show the variation in subsurface properties from Mt. Lawu to Mt. Muriah. In the south position, there is a high Bouguer anomaly, which indicates the Mt. Lawu intrusion.

The low Kendeng zone has a lower Bouguer anomaly, showing the deep basement and very thick sediment. Smyth et al. in reference [8] hypothesized that the Kendeng zone is probably a crust of metamorphosed ophiolitic rock and has an arch like character. The Bouguer anomaly in this region indicates that this area is not thinner to the south, but it is depressed by the loading of the volcanoes.

Based on the Bouguer anomaly modelling and some authors [7, 17], the depth of the sediment in Lower Kendeng zone is more than 5000 meters. The high Kendeng zone, however, has a higher Bouguer anomaly, which indicates that the basement is shallow. The presence of a thrust fault in this area causes shallowing of the basement. The cherts found on the surface around the main crater of the Bledug Kuwu mud eruption, as shown in Figure 10b, indicate the presence of a shallow basement in high-elevation areas of the Kendeng zone. Outcrop samples in the high Kendeng zone also shows various lithologies of young and old formations. A smaller value 
Table 3: Temperature and thermal gradient measurements along the survey line.

\begin{tabular}{|c|c|c|c|c|c|c|}
\hline No. & Location Name & $\begin{array}{l}\text { Position from } \\
\text { North (base } \\
\text { point) (in } \\
\text { Km) }\end{array}$ & $\begin{array}{l}\text { Thermal } \\
\text { Gradient } \\
\left({ }^{\circ} \mathrm{C} / 100\right. \\
\mathrm{m})\end{array}$ & $\begin{array}{l}\text { Temperature } \\
\text { at top water } \\
\text { table (deg } \\
\text { Celsius) }\end{array}$ & $\begin{array}{l}\text { Elevation } \\
\text { Corrected } \\
\text { (Meters } \\
\text { form mean } \\
\text { sea level) }\end{array}$ & Remarks \\
\hline 1 & $\begin{array}{l}\text { Sinanggul } \\
\text { Tengah }\end{array}$ & 0.00 & 1.01 & 29.1 & 34.4 & North \\
\hline 2 & Payak 1 & 4.91 & 1.67 & 26.5 & 294.2 & \\
\hline 3 & Lebak & 6.76 & 1.14 & 28.6 & 119 & \\
\hline 4 & Tayu 1 & 8.12 & 3.33 & 31.4 & -11 & \\
\hline 5 & Lau 1 & 23.92 & 1.05 & 27.9 & 260.7 & \\
\hline 6 & Plosorejo 1 & 25.53 & 1.11 & 28.3 & 142 & \\
\hline 7 & Plosorejo 3 & 25.54 & 1.54 & 28.4 & 145.5 & \\
\hline 8 & Muktiharjo & 28.74 & 1.67 & 29.2 & 49.2 & \\
\hline 9 & Muktiharjo 2 & 28.74 & 1.43 & 29.2 & 51 & \\
\hline 10 & Koripandriyo 1 & 31.06 & 2.50 & 29.6 & 17 & \\
\hline 11 & Tanjung Anom & 40.32 & 1.33 & 29.3 & 27 & \\
\hline 12 & Mangunrekso & 45.95 & 1.67 & 28.5 & 29.6 & \\
\hline 13 & Karangawen & 46.83 & 3.00 & 28.7 & 32 & \\
\hline 14 & Maitan 1 & 52.98 & 6.67 & 27.8 & 306 & \\
\hline 15 & Pager gunung & 57.63 & 6.11 & 27 & 278 & \\
\hline 16 & Tambakselo & 64.66 & 3.75 & 29 & 65 & \\
\hline 17 & Bledug Kuwu & 72.45 & 2.37 & 30.8 & 90 & \\
\hline 18 & Crewek & 77.22 & 1.30 & 28.1 & 63 & \\
\hline 19 & Posong & 84.76 & 2.08 & 28.1 & 173 & \\
\hline 20 & Ds. Bago & 85.86 & 2.08 & 27 & 138 & \\
\hline 21 & Keras 1 & 87.09 & 1.88 & 28.6 & 147 & \\
\hline 22 & Keras 3 & 87.99 & 1.43 & 28.6 & 179 & \\
\hline 23 & Jatisomo & 99.84 & 1.58 & 27.3 & 88.8 & \\
\hline 24 & Karangmalang & 107.16 & 2.17 & 28.6 & 90.77 & \\
\hline 25 & Ds. Wareg & 108.31 & 1.11 & 27.7 & 120 & \\
\hline 26 & Ngunut & 116.05 & 1.38 & 30 & 120 & \\
\hline 27 & Jetis & 118.11 & 1.18 & 29 & 478.9 & \\
\hline 28 & Menjing & 119.08 & 1.80 & 30 & 492 & \\
\hline 29 & Kondo & 120.88 & 1.82 & 30 & 670 & \\
\hline 30 & Trengguli & 121.80 & 1.81 & 31 & 721 & \\
\hline 31 & Prabon & 125.94 & 7.04 & 33 & 611 & \\
\hline 32 & Pablengan & 126.98 & 11.42 & 35.6 & 450 & \\
\hline 33 & Salaman & 127.51 & 11.42 & 34 & 455 & \\
\hline 34 & Cumpleng & 130.38 & 13.53 & 33.8 & 673 & \\
\hline 35 & Lawu & 132.70 & 17.1 & 35.3 & 680 & South \\
\hline
\end{tabular}


of Bouguer anomaly at the low elevation of Pati may correlate with paleo-straits in this area. In the northern part of the survey line, Mt. Muriah has a high Bouguer anomaly. Figure 13 shows the subsurface geological model based on Bouguer anomaly data; it considers various constraints, including the density of the lithology, as shown in Table 1.

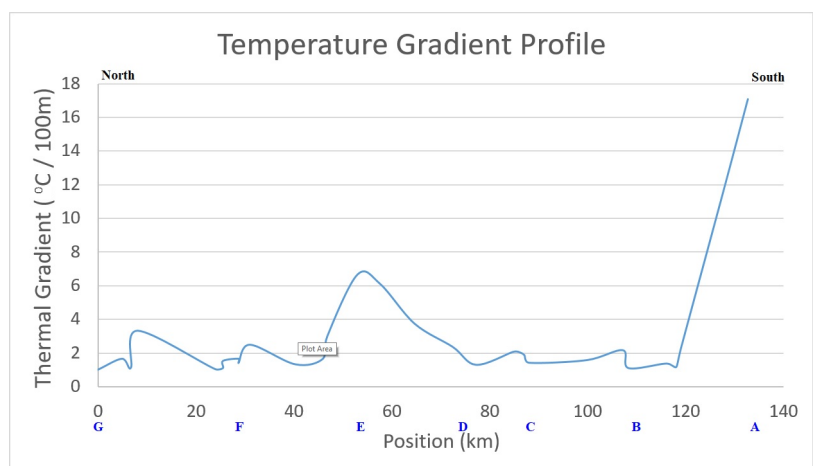

Figure 8: Temperature gradient profile along the measurement line.

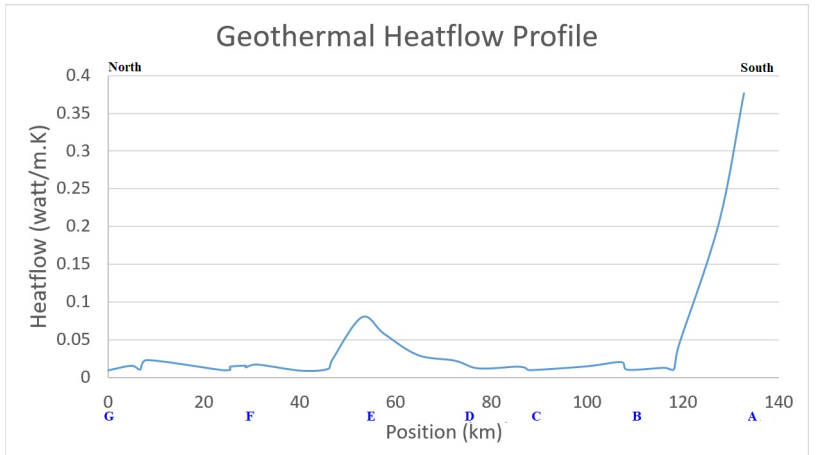

Figure 9: Geothermal heat flow profile along the measurement line.

\subsection{Subsurface Thermal Conductivity Modeling}

The subsurface geology model that was obtained based on the Bouguer anomaly data was transformed into a model of thermal conductivity in order to calculate the subsurface temperature model using Equation (1). The process of transforming geological models in the domain of density into thermal conductivity was carried out using the density and thermal conductivity relationships in all rock samples measured in the laboratory. The resulting subsurface thermal conductivity model is shown in Figure 15.

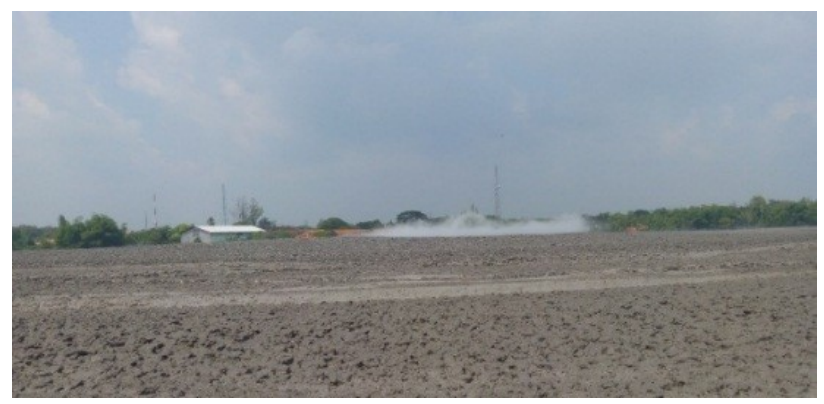

(a)

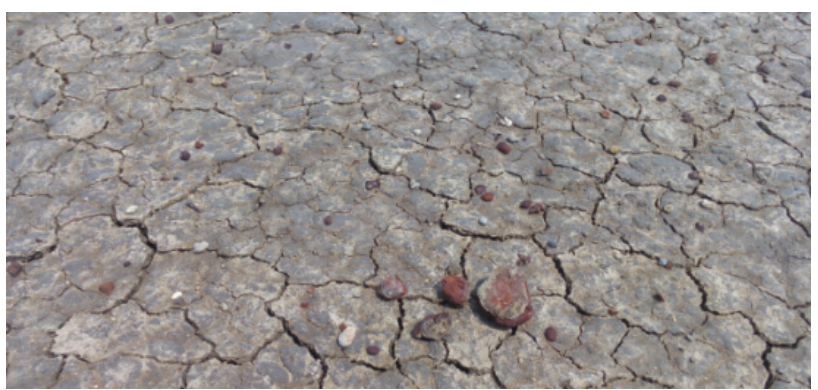

(b)

Figure 10: Bledug Kuwu mud eruption: (a) a bubble bursting during mud eruption; (b) cherts transported upwards due to the high viscosity of the erupted mud.

\subsection{Subsurface Temperature Modeling}

The subsurface temperature was calculated by using the finite difference of Fourier's law of Equation (1). This equation shows the relation between heat flow $(\mathrm{Q})$, thermal conductivity ( $\mathrm{k})$, and the temperature gradient (dT/dz).

$$
Q=k d T / d z
$$

The subsurface temperature can be estimated by forward modeling of temperature from the surface to the deeper zone using various input data, as shown in the workflow in Figure 4. The modeling integrates many generated input data such as surface temperature, temperature gradient, geothermal heat flow, and the subsurface thermal conductivity model to produce an integrated subsurface temperature model. Once the value of geothermal heat flow was available, we used the workflow of the integrated temperature modeling in Figure 4 to estimate the subsurface temperature beneath the survey line by applying temperature data from the 35 wells.

Figure 16 shows the result of subsurface temperature modeling along the survey line. The temperature profile beneath the survey line illustrates the mechanism of many phenomena in the subsurface areas of Mt. Lawu, the Kendeng zone, and Mt. Muriah. 


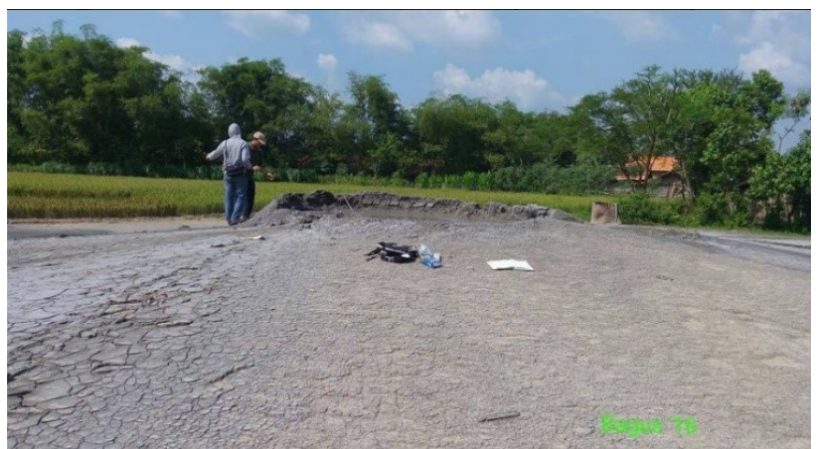

Figure 11: Active mud eruption in the Kendeng zone.

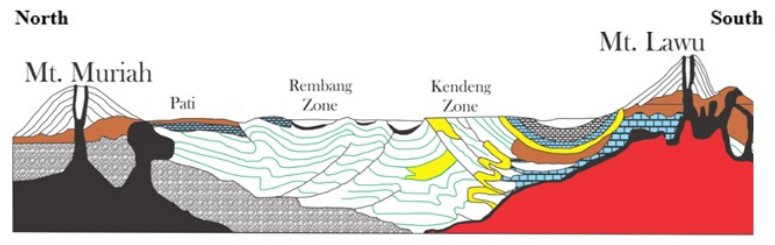

Figure 12: Geology model, south to north; from [5], [14], [21], and [22], with modifications.

\section{Discussion}

The geothermal heat flow and subsurface temperature modeling along the survey line shows the differences between the two volcanoes: Mt. Muriah and Mt. Lawu. Mt. Lawu has high geothermal heat flow and high subsurface temperatures. Some direct field observations at Mt. Lawu revealed that this volcano is still active today. Meanwhile, Mt. Muriah has a small value of geothermal heat flow. Figure 16 shows the subsurface temperature of Mt. Muriah, which confirms the low subsurface temperature. Field observations of Mt. Muriah showed a lack of geothermal activity, such as hot springs, fumaroles, or active craters. Since Mt. Muriah has low geothermal heat flow and low subsurface temperatures, Mt. Muriah is now considered a dormant volcano.

The Kendeng zones had a relatively high subsurface temperature and high geothermal heat flow, as shown in Figure 9 and Figure 16, respectively. This phenomenon is interesting, since the surface observations, as well as the geological reports, indicate no volcanic activity in the Kendeng zone. The thrust fault of the Kendeng zone, however, has been active since the Pliocene and is still active in the present day. The position of the Kendeng zone is also far from Mt. Lawu, which is $60-70 \mathrm{~km}$ from the belt of active volcanoes in southern Java Island. In addition, earthquake measurements show vibration in the high Kendeng zone, and there are some spots of sulphur pools,

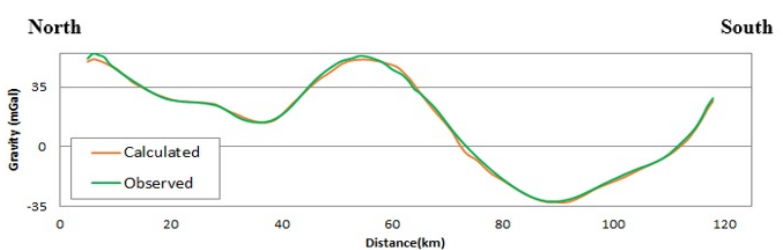

(a)
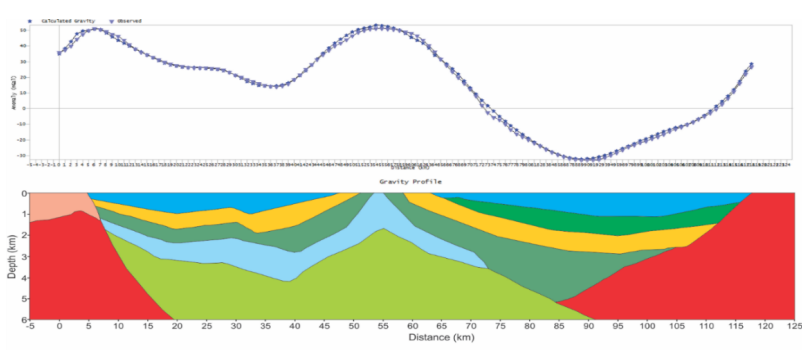

(b)

Figure 13: Subsurface geology modeling considering various input data. (a) Bouguer anomaly along the line of measurement, with an average error of 0.07 ; (b) the subsurface geology model.

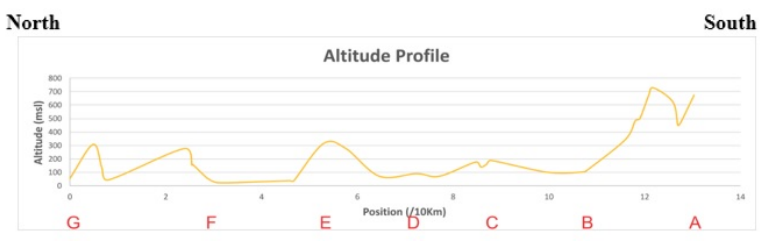

Figure 14: Elevation profile along the measurement line.

including the active mud eruption in Bledug Kuwu. Some direct measurements at the surface of Bledug Kuwu mud eruption showed relatively high temperatures, about $33^{\circ} \mathrm{C}$, which was higher than the temperature of the water table of surrounding wells, which had an average of temperature $29^{\circ} \mathrm{C}$.

There are many active mud eruptions in the Kendeng zone called the area of Kradenan mud eruption. The Bledug Kuwu is the biggest mud eruption in the Kradenan mud eruption area. The position of the Kradenan mud eruption areas is shown as point D in Figure 1. The mud eruption called Bledug Kuwu is not a continuous flow; it is an intermittent flow which is controlled by the buoyancy of gas bubbles. The flow mechanisms of Bledug Kuwu and the Kradenan mud eruption are analogous to that of the Lusi mud eruption in Sidoarjo [7].

The mud eruption in Bledug Kuwu erupts intermittently by releasing gas bubbles of mud. The biggest mud crater emits gas bubbles with a very sharp smell. The smell of the gas indicates the sulfur content of the gas coming out of the crater. Figure 10(a) shows the phenomena of 


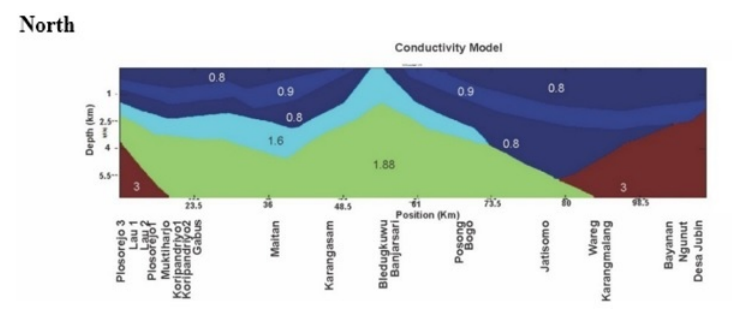

Figure 15: The thermal conductivity of the subsurface layer along the line of measurement. The numbers in the sections indicate thermal conductivity in $\mathrm{W} / \mathrm{mK}$.

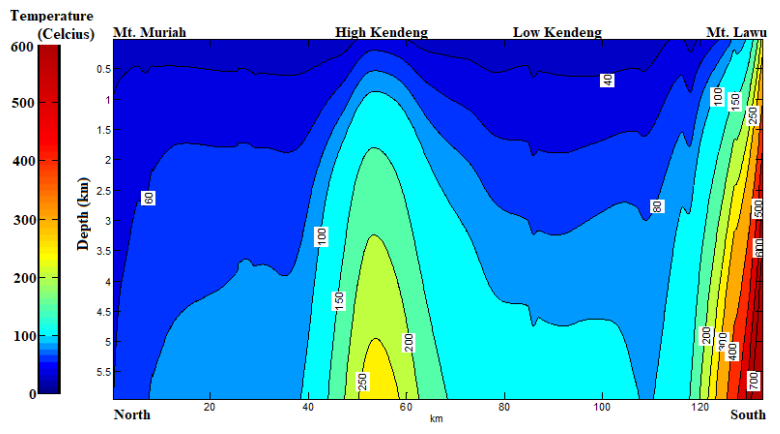

Figure 16: The subsurface temperature model along the measurement line. The temperature color scale is in degrees Celcius.

mud bubble eruption. The mud bubble eruption period in the largest mud crater is around 20-30 seconds. Figure 10(b) presents the chert rocks that are carried upwards due to high-viscosity mud eruptions. The white crystal in the photograph of Figure 10(b) illustrates the content of salt crystals, which indicates that the subsurface environment is paleo-marine. The erupted water $\mathrm{pH}$ is 5.5 , which means that the fluid tends to be acidic. Also, the conductivity of the water is more than two millisiemens. The average temperature inside the Bledug Kuwu mud crater is higher than the surrounding water table's temperature. There is evidence of volcanic activity in this area, such as the eruption of high-temperature mud, an acid environment, and the presence of sulfur gas.

The subsurface high-temperature phenomenon and high geothermal heat flow in the Kendeng Hill zone (denoted by D and E in Figure 9) may correlate with several possibilities: volcanic activity, main fault activity in this area, or the presence of high-conductivity thermal layers due to the presence of fluid within the fractures. The details of some possibilities are as follows:

- The recent fault activities, especially thrust faults, may generate thermal heating due to the work of friction force. Furthermore, the row of Kendeng Hill is a product of thrust fault stress, which is able to produce significant friction force and displacement. There are many spots of thousands of years' mud eruption in the high Kendeng zone, which are still flowing today. Several authors have also researched the mechanism of heat generation during faulting processes (e.g., [2-4] and [24]).

- Figure 10 and Figure 11 show the craters of mud eruption in the Kendeng Hills. The energy which caused thousands of years of mud eruption may be raised up by high thermal heating in the deep subsurface. When the heated mud exceeds the bubble point, it can generate a pumping mechanism of mud by gas bubbles [7]. Gas bubbles decrease the density of mud, and then this viscous fluid can be lifted up to the surface intermittently.

- There is the possibility that subsurface volcanic activity occurred in the Kendeng zone. The possibility exists that subsurface volcanic activity still occurs, since there are many active volcanoes in East Java. The recent active volcanic belt is in the south of East Java-the row of active mountains includes, from west to east, Mt. Lawu, Mt. Wilis, Mt. Arjuna, Mt. Bromo, Mt. Semeru, Mt. Argapura, and Mt. Raung. The high Kendeng zone, however, is a row of carbonate hills in the middle of East Java. The Kendeng hills lie from the west to the east of the middle of East Java Island. Some studies and our surface observations showed no high volcanic activity in the Kendeng hills, such as no active volcano crater, no volcanic rocks at the surface, and no fumaroles. However, some hot springs exist in the northern part of the Kendeng carbonate hills, such as Prataan hot spring near Bojonegoro, Nganget hot spring near Tuban, and Jatikalen hot spring near Nganjuk. These hot springs are in the Kendeng Hill area. Also, there is a water spring containing sulfur in Dermawuharjo village, near Tuban, of northern Java Island. These phenomena show the presence of volcanic activity in the subsurface of the Kendeng zone, but this still needs some further studies.

- The highly thermal conductive layers beneath the Kendeng zone may generate high geothermal heat flow, which transfers heat from the row of volcanic mountains in the south of East Java. Metal contents and metamorphic rock have high thermal conductivity. We found chert with high thermal conductivity in the Kendeng Hills. Several authors have confirmed that the presence of fluid-filled fractures also increases the thermal conductivity (i.e., [25]). In the Kendeng Hills, the highly thermal conductive layer was lifted by thrust faults, meaning that heat can be transferred more significantly from a deep heat source to the surface. Highly thermal conductive layers prop- 
agate more significant heat flow from the heat source, beneath the active row of volcanic mountains in the south of East Java, toward a zone $50-70 \mathrm{~km}$ to the north. The presence of chert rock surrounding mud eruption sites indicates that the basement is uplifted in the Kendeng zone (see Figure 10b). Basement rock usually has higher thermal conductivity. Future research is needed regarding the anisotropy of thermal conductivity in the basement of Kendeng.

\section{Conclusions}

We proposed an integrated subsurface temperature model using various input data: surface temperature, temperature gradient, the conductivity of rock, a subsurface geology model, and subsurface thermal conductivity. The subsurface thermal conductivity model uses a geology model as a reference. We measured the thermal conductivity of various lithologies in each formation of East Java basin.

The subsurface temperature profile along the line of measurement shows low subsurface temperatures for the dormant volcano of Mt. Muriah, and the active volcano of Mt. Lawu shows high subsurface temperatures. The geothermal heat flow was observed from 35 wells, from Mt. Lawu in the southeast to Mt. Muriah in the northwest of the North East Java Basin, along $130 \mathrm{~km}$ approximately.

There are newfound phenomena beneath the Kendeng Hills zone, which has a high subsurface temperature and relatively high geothermal heat flow. The significant heat beneath the Kendeng zone has a few possible explanations, such as recent fault activities or subsurface volcanic activities.

Acknowledgements: This research is fully supported by an Indonesian Ministry of Research, Technology and Higher Education research grant. The research is also supported by Rock Fluid Imaging Lab which provided the laboratory equipment. We want to express our thanks to Dr. Djedi S. Widarto of Pertamina Research Technology Center and Dr. Karoly Nemeth for their invaluable review of our paper.

\section{References}

[1] Rühaak W., Bär K., Sass I., Combining numerical modeling with geostatistical interpolation for an improved reservoir exploration, Energy Proc., 2014, vol. 59, pp. 315-322, DOI:10.1016/j.egypro.2014.10.383.
[2] Agemar T., Schulz R., Subsurface Temperature Distribution in Germany, Geothermics, 2012, vol. 44, pp. 65-77, DOI:10.1016/j.geothermics.2012.07.002.

[3] Bonte D., Guillou-Frottier L., Garibaldi C., Bourgine B., Lopez S., Bouchot V. , Lucazeau F., Subsurface temperature maps in French sedimentary basins: New data compilation and interpolation, Soc. Geo. de France, 2010, pp. 377-390, DOI:10.2113/gssgfbull.181.4.377.

[4] Nurhandoko B. E. B., Shale Gas Reservoir Characterization Strategy, HAGI-IAGI, Indonesia, 2013.

[5] Bemmelen R. V., The Muriah Volcano (Central Java) and the origin of its leucite-bearing rocks, K. Ned. Akad., 1947, vol. Wet. 50, pp. 653-658.

[6] Sukardi B. T., Explanatory note and geological map of Salatiga Quadrangle, Jawa (Scale 1 : 100.000)., Geol. Research and Dev. Center, PPPG Bandung, Indonesia: Quadrangle, 1992, 1408-6.

[7] Satyana A., Djumlati M., Oligo-Miocene Carbonates of the East Java Basin, Indonesia: Facies Definition Leading to Recent Significant Discoveries, AAPG, Barcelona, Spain, 2003.

[8] Smyth H., Hall R., Hamilton J., Kinny P., Volcanic origin of quartzrich sediments in East Java, IPA Proc., Jakarta, 2003.

[9] Lunt P., The Sedimentary Geology of Java, IPA, 2013.

[10] Smyth H., Hall R., Hamilton J., Pete K., East Java: Cenozoic basins, volcanoes and ancient basement, IPA, pp. 251-266., Jakarta, Indonesia, 2005.

[11] Suwarti T., Wikarno R., Peta geologi lembar Kudus, Jawa, PPPG, 1992.

[12] Kadar D., Sudijono, Peta Geologi Bersistem Indonesia Lembar Rembang 1509-1 \& 4 Skala 1:100.000, PPPG, Indonesia, 1993.

[13] Datun M., Sukandarrumidi B., Hermanto, Suwarna N., Peta geologi lembar Ngawi, Jawa, PPPG, 1996.

[14] Sampurno, Samudra H., Peta Geologi Lembar Ponorogo, Jawa, Ed Kedua. Bakortanal, Jakarta, 1997.

[15] Nurhandoko B.E.B., Listyobudi M., Rizal I., Kurniadi R., Susilowati, Purnama A. D., Kusharyo D., Geothermal Heat Flow Measurement for Predicting Subsurface Temperature Distribution, ITB Geothermal Proc., 2013.

[16] Simo T., Sekti R. P., Hakiki F., Sun M., Myers R. D., Fullmer S., Reservoir Characterization and Simulation of an OligoceneMiocene Isolated Carbonate Platform: Banyu Urip Field, East Java Basin, Indonesia,GTW, AAPG, 2012.

[17] Sujanto F. X., Sumantri Y., Preliminary Study On the Tertiary Depositional Patterns of Java, IPA Proc., 1977.

[18] Syarif N., Suharyono S., Subagio, Peta Anomali Bougouer Lembar Surabaya-Sapulu, Jawa, PPPG, 1994.

[19] Clauser C. and Huenges E., Thermal Conductivity of Rocks and Minerals, Rock Physics and Phase Relations, A Handbook of Physical Constants AGU Reference Shelf 3, the American Geophysical Union, 1995.

[20] Kanamori H., Anderson D., and Heaton T., Frictional melting during the rupture of the 1994 Bolivian Earthquake, Sci., 1998, vol. 279, p. 839-842.

[21] Mase C., Smith L., Effects of frictional heating on the thermal, hydrologic, and mechanical response of a fault, Geophysical Res. J., 1987, vol. 92, p. 6249-6272.

[22] Rice J., Heating and weakening of faults during earthquake slip, Geophysical Res. J., 2006, Vols. 111, B05311.

[23] Cyranoski D., Indonesian eruption: Muddy waters, Nature, 2007, vol. 445 , pp. 812-815. 
[24] Nurhandoko B.E.B., Is mudflow in Sidoarjo, East Java due to the pumping mechanism of hot air bubbles? : Laboratory simulations and field observations, ICMNS, 2015, DOI:10.1063/1.4930682.

[25] Nicholls I. A., Whitford D., Potassium-rich volcanic rocks of the Muriah complex, Java, Indonesia: Products of multiple magma sources?, Volc. and Geothermal Res. J., 1983, vol. 18, pp. 337 359.

[26] Hall R., Cenozoic Geological and Plate Tectonic Evolution of SE Asia and the SW Pacific Computer-based Reconstructions, Model, and Animations, Asian Earth Sci. J., 2002, vol. 20(4), pp. 353-431.
[27] McKenzie D, Brune J., Melting on Fault Planes during Large Earthquakes, Geophysical J. of the Royal Astronomical Soc., 1972, vol. 29, p. 65-78.

[28] Satyana A. H., Armandita C., Deepwater Plays of Java, Indonesia: Regional Evaluation pn Opportunities and Risks, IPA, 2004.

[29] Sribudiyani, Prasetya I., Muchsin N., Sapiie B., Ryacudu R., Asikin S., Kunto T., Harsolumakso A., Astono P., Yulianto I., The Collision of the East Java Microplate and Its Implication for Hydrocarbon Occurrences in The East Java Basin, IPA, Jakarta, 2003.

[30] Putra S. D. H., S., Srigutomo W., Thermal modeling and heat flow density interpretation of the onshore Northwest Java Basin, Indonesia, Geothermal Energy, 2016, DOI:10.1186/s40517-0160052-x. 